\title{
ANALISIS EMPIRICAL ORTHOGONAL FUNCTION (EOF) DAN TRANSFORMASI FOURIER PADA SINYAL CURAH HUJAN INDONESIA
}

\author{
P. SEPTIAWAN ${ }^{1}$, S. NURDIATI ${ }^{2}$,A.SOPAHELUWAKAN ${ }^{3}$
}

\begin{abstract}
Abstrak
Curah hujan merupakan parameter atmosfer yang sulit diprediksi karena memiliki keragaman yang tinggi baik secara spasial dan temporal. Tujuan penelitian ini adalah menganalisis frekuensi sinyal curah hujan enam bulanan dan pola curah hujan harian Indonesia secara spasial dan temporal untuk mendapatkan variasi diurnal. Analisis transformasi Fourier digunakan untuk mengetahui pengaruh sinyal curah hujan enam bulan terhadap curah hujan Indonesia pada data TRMM 3B43. Hasil analisis menunjukkan wilayah Indonesia yang terbagi menjadi tiga tipe hujan memiliki kekuatan sinyal curah hujan enam bulanan yang berbeda-beda dengan urutan kekuatan sinyal berturut-turut monsoonal, ekuatorial, kemudian lokal. Analisis EOF berbasis dekomposisi nilai singular digunakan untuk mereduksi data TRMM 3B42 dan mendapatkan pola-pola dominan secara spasial dan temporal. Hasil analisis pada tiga pola dominan utama dari 2920 pola menunjukkan pola dominan pertama didominasi oleh pola hujan enam bulanan, sedangkan variasi diurnal diperoleh pada pola dominan kedua dan ketiga.
\end{abstract}

Kata kunci: curah hujan TRMM 3B42, curah hujan TRMM 3B43, dekomposisi nilai singular, empirical orthogonal function (EOF), transformasi Fourier.

\section{PENDAHULUAN}

Curah hujan merupakan salah satu parameter atmosfer yang sulit diprediksi karena mempunyai keragaman tinggi baik secara spasial maupun temporal. Demikian halnya dengan curah hujan di wilayah maritim tropis seperti Indonesia. Sebagai negara kepulauan, Indonesia memiliki tiga pola hujan, yaitu: monsoonal, ekuatorial, dan lokal. Setiap pola curah hujan tersebut memiliki karakteristik dan penyebab masing-masing..

Pola yang paling mendominasi adalah pola monsoonal yaitu pola periode hujan dua belas bulanan yang terdiri atas satu kali musim hujan dan satu kali

1 Mahasiswa S1Program Studi Matematika, Departemen Matematika, Fakultas Ilmu Matematika dan Pengetahuan Alam,Jalan Meranti Kampus IPB Dramaga Bogor, 16680. Email: septiawan_pandu@gmail.com

2 Departemen Matematika,Fakultas Ilmu Matematika dan Pengetahuan Alam, Jalan Meranti Kampus IPB Dramaga Bogor, 16680.

${ }^{3}$ Pusat Penelitian dan Pengembangan, Badan Meteorologi, Klimatologi dan Geofisika, Jl. Angkasa I No.2 Kemayoran, Jakarta Pusat, DKI Jakarta 10720 
musim kemarau. Hal ini dipengaruhi oleh angin monsoon yang bertiup akibat adanya perbedaan musim antara belahan bumi utara dan selatan. Selain itu beberapa daerah di Indonesia juga memiliki pola ekuatorial, sehingga daerah di sekitar ekuator memiliki dua kali musim hujan atau memiliki periode hujan enam bulanan. Pola ekuatorial ini dipengaruhi oleh gerak revolusi bumi mengelilingi matahari dan pengaruh zona konvergensi terhadap hujan (inter tropical convergenze zone), sehingga diperlukan sebuah metode yang disebut transformasi Fourier untuk menganalisis kedua pola tersebut. Dalam penelitian ini, kita dapat mengetahui pengaruh dari pola monsoonal, pola ekuatorial, dan pola hujan lokal dalam memengaruhi periode musim hujan di Indonesia.

Pola hujan lokal adalah pola hujan yang disebabkan oleh topografi dan keadaan lingkungan suatu daerah. Indonesia mempunyai garis pantai yang panjang dan wilayah berpegunungan, sehingga memengaruhi arus udara, perubahan cuaca, iklim, dan hujan. Selain itu, Indonesia mempunyai variasi suhu yang kecil, sementara variasi curah hujan yang besar. Hal ini disebabkan karena curah hujan di Indonesia dipengaruhi oleh beberapa faktor. Salah satunya adalah variasi diurnal.

Variasi diurnal merupakan sinyal berskala kecil yang memengaruhi curah hujan harian di Indonesian. Variasi diurnal disebabkan oleh dua hal, yaitu adanya lautan dan daratan, dan ukuran pulau dan topografi dari pulau yang sesuai. Akan tetapi variasi diurnal ini sinyalnya sangat kecil jika dibandingkan dengan sinyalsinyal lain yang memengaruhi curah hujan seperti pada periode yang lebih panjang dan skala yang lebih besar, sehingga perlu analisis tertentu agar dapat melihat sinyal diurnal tersebut.

Data curah hujan merupakan data berbentuk matriks yang memiliki dimensi yang cukup besar dan sulit untuk dianalisis. Oleh karena itu, dibutuhkan cara yang tepat untuk menganalisis data tersebut agar diperoleh informasi yang bermanfaat. Ada beberapa cara untuk menyelesaikan suatu permasalahan yang berkaitan dengan dimensi data matriks yang cukup besar. Salah satunya adalah dengan mereduksi dimensi matriks data tersebut dengan metode singular value decomposition (SVD).

Oleh karena itu, pada penelitian ini diberikan data curah hujan setiap 3 jam tropical rainfall measuring mission (TRMM) 3B42 dan data curah hujan setiap bulan TRMM 3B43 untuk wilayah Indonesia. Analisis dilakukan menggunakan transformasi Fourier dan metode EOF berbasis singular value decomposition (SVD) untuk mereduksi data tersebut. Selanjutnya akan dianalisis pola spasial dan pola temporal dari hasil reduksi data dan dianalisis sinyal dominan yang memengaruhi curah hujan wilayah Indonesia. Manfaat Penelitian ini adalah memberikan pengetahuan baru kepada masyarakat Indonesia yang didasarkan pada data aktual curah hujan Indonesia tentang periode hujan dan pola-pola hujan yang memengaruhi curah hujan di Indonesia. Pengetahuan ini dapat digunakan untuk membuat prediksi terhadap curah hujan menjadi lebih akurat. Selain itu juga dapat membuat petani dan pemerintah dapat lebih tepat dalam menentukan 
masa tanam dan jenis tanaman yang ditanam sesuai dengan daerah masingmasing, agar mendapatkan hasil panen yang maksimal.

\section{Tinjauan Pustaka}

\subsection{Transformasi Fourier}

Transformasi Fourier merupakan suatu metode untuk mentransformasikan suatu sinyal dari domain waktu ke dalam domain frekuensi. Transformasi Fourier didefinisikan sebagai

$$
\begin{aligned}
& F(v)=\int_{-\infty}^{\infty} f(x) e^{-i 2 \pi v x} d x(1) \\
& f(x)=\int_{-\infty}^{\infty} F(v) e^{i 2 \pi v x} d v
\end{aligned}
$$

di mana

$$
\begin{aligned}
& f(x)=\text { fungsi atau sinyal dalam domain waktu, } \\
& e^{-i 2 \pi v x}=\text { fungsi kernel, } \\
& F(v) \quad=\text { fungsi dalam domain frekuensi, } \\
& v \quad=\text { frekuensi. } \\
& x \quad=\text { waktu. }
\end{aligned}
$$

Fungsi $f$ dan $F$ disebut sebagai pasangan transformasi Fourier. Persamaan (1) disebut sebagai transformasi maju (analisis) dan persamaan (2) disebut sebagai transformasi invers (sintesis).

\subsection{Discrete Fourier Transform}

(Wiley 2014).

Didefinisikan $f \in \mathbb{C}^{N}$ adalah suatu vektor, kemudian

$$
f(n)=\frac{1}{N} \sum_{m=0}^{N-1} F(m) \exp \left(\frac{i 2 \pi m n}{N}\right), \quad n=0,1,2, \ldots, N-1
$$

dengan $F \in \mathbb{C}^{N}$ adalah discrete Fourier transform dari $f$,

$$
F(m)=\sum_{n=0}^{N-1} f(n) \exp \left(-\frac{i 2 \pi m n}{N}\right), \quad m=0,1,2, \ldots, N-1
$$

dengan $n=$ indeks dalam domain waktu $=0,1, \ldots, N-1$,

$m=$ indeks dalam domain frekuensi $=0,1, \ldots, N-1$. 
Fungsi $f$ dan $F$ disebut sebagai pasangan discrete Fourier transform (DFT). Persamaan (4) disebut sebagai transformasi maju (analisis) dan persamaan (3) disebut sebagai transformasi invers (sintesis).

(Wiley 2014).

\subsection{Fast Fourier Transform}

DFT merupakan alat praktis yang penting karena ada algoritme yag efisien untuk menghitungnya. Salah satunya adalah algoritme yang paling popular yaitu fast Fourier transform (FFT). Perhitungan langsung pada DFT pada umumnya membutuhkan $N$ perkalian dan $N-1$ penjumlahan untuk setiap $N$ elemen dari $F$. Jika $f$ bilangan kompleks, setiap perkalian masig-masing terhadap diri sendiri membutuhkan empat perkalian real dan dua penjumlahan real:

$$
(a+i b)(c+i d)=(a c-b d)+i(b c+a d) .
$$

Setiap $N-1$ penjumlahan bilangan kompleks membutuhkan dua penjumlahan bilangan real: $(a+i b)+(c+i d)=(a+c)+i(b+d)$.

Total operasi yang diperlukan adalah $4 N^{2}$ perkalian bilangan real dan $4 N^{2}$ $2 N$ penjumlahan bilangan real. Pada pemrosesan digital, penjumlahan-perkalian dilakukan dalam satu operasi tanpa harus membuat jalur terpisah antara penjumlahan dan perkalian, sehingga membutuhkan $4 N^{2}$ operasi bilangan real. Jika $f$ bilangan real, membutuhkan $2 N^{2}$ operasi bilangan real. Karena $F$ merupakan matriks Hermitian, akan mengurangi setengah jumlah operasi, sehingga perhitungan langsung DFT membutuhkan $N^{2}$ operasi. Perhitungan tersebut akan menimbulkan galat $O\left(N^{2}\right)$.

Pada Algoritme FFT, galat yang ditimbulkan adalah $O\left(N \log _{2} N\right)$ ketika $N$ adalah nilai pangkat dari 2. Meskipun dalam transformasi kecil, contohnya $N=$ 32, perbedaannya adalah 170 FFT operasi dengan 1024 DFT. Ketika $N=512$, perbedaannya sangat besar yaitu 4600 FFT dengan 256000 DFT.

(Wiley 2014)

\subsection{Singular Value Decomposition (SVD)}

Misalkan $X$ sebarang matriks berukuran $n \times p$ dengan $\operatorname{rank}(X)=r$. Singular value decomposition (SVD) atau dekomposisi nilai singular dari $X$ adalah faktorisasi dalam bentuk:

$$
X=U \sum V^{T}
$$

dengan $U=\left[u_{1}, u_{2}, \ldots, u_{n}\right]$ dan $V=\left[v_{1}, v_{2}, \ldots, v_{n}\right]$ merupakan matriks ortogonal. Matriks $U$ berukuran $n \times n, V$ berukuran $p \times p$, dan $\sum=\left[\begin{array}{ll}\sigma & 0 \\ 0 & 0\end{array}\right]$ adalah matriks berukuran $n \times p$ dengan $\sigma=\operatorname{diag}\left(\sigma_{1}, \sigma_{2}, \ldots, \sigma_{n}\right)$ dan $\sigma_{1} \geq \sigma_{2} \geq \ldots \geq \sigma_{n} \geq 0$. 
Dimana $\sigma_{i}$ merupakan nilai singular dari matriks $X, U$ dan $V$ masing-masing merupakan vektor singular kiri dan vektor singular kanan dari matriks $X$. Oleh karena itu, dapat dituliskan

$$
X_{n \times p}=U_{n \times n}\left[\begin{array}{ll}
\sigma & 0 \\
0 & 0
\end{array}\right]_{n \times p} V_{n \times p}^{T}
$$

(Nicholson 2001).

\section{Teorema 2.1}

Diberikan $X$ sebarang matriks berukuran $n \times p$ dengan ciri $\operatorname{rank}(X)=r$ dan nilai singular $\sigma_{1} \geq \sigma_{2} \geq, \ldots \geq \sigma_{i}$. Jika didefinisikan $U, \sum$,dan $V$ seperti uraian di atas, maka $U$ dan $V$ matriks ortogonal dan $A$ dapat didekomposisikan sebagai

$$
X=U \sum V^{T}
$$

Bukti dapat dilihat pada Leon (2014).

\subsection{Empirical Orthogonal Function (EOF)}

Analisis EOF bertujuan untuk mentransformasikan $p$ peubah asal yang saling berkorelasi menjadi $k$ buah komponen ortogonal (tidak berkorelasi). Misalkan $X$ matriks berukuran $n \times$ pyang mengandung dataset dengan $n$ banyaknya peubah atau variabel dan $p$ waktu. SVD dari $X$ dengan $\operatorname{rank}(X)=r$ adalah faktorisasi seperti pada persamaan (5) sehingga diperoleh

$$
X=\sum_{i=1}^{r} u_{i} \sigma_{i} v_{i}(k) \text {. }
$$

Matriks Vdari persamaan (5) adalah matriks EOF atau koefisien vektor dan $U \sum$ adalah matriks skor EOF atau komponen utama. Skor komponen utama dapat dituliskan

$$
z_{i}=u_{i} \sigma_{i}, i=1,2, \ldots, r .
$$

Varian dari $i$ komponen utama $i=1,2, \ldots$, radalah

$$
\mu_{i}=\frac{\sigma_{i}^{2}}{\sum_{i=1}^{r} \sigma_{i}^{2}}
$$

dengan , $i=1,2, \ldots, r$ merupakan nilai singular dari matriks $\mathrm{X}$.

Dalam prakteknya, $k$ mode EOF1 atau komponen utama pertama dengan $k \ll r$ menjelaskan proporsi varian terbesar. Mode EOF2 merupakan kombinasi linear dari seluruh variabel yang diamati yang bersifat ortogonal terhadap mode EOF1 dan memiliki varian terbesar kedua dan seterusnya. Oleh karena itu, mode EOF ke- $k$ memiliki varian maksimum ke- $k$ dan tidak berkorelasi dengan mode EOF sebelumnya. Analisis EOF digunakan untuk mencari $n \times p$ matriks skor komponen dari $n$ objek pengamatan dan $p$ waktu. 
(Hannachi 2009)

\section{METODE}

\subsection{Metode Penelitian}

Tahapan ini diawali dengan studi literatur yang berkaitan dengan metode yang akan digunakan yaitu metode transformasi Fourier dan EOF berbasis SVD terhadap data curah hujan. Metode transformasi Fourier digunakan untuk mengubah sinyal dari domain waktu menjadi sinyal dengan domain frekuensi. Hal ini digunakan untuk memperoleh sinyal sinyal dominan terkait periode hujan pada data curah hujan TRMM 3B43 wilayah Indonesia. Metode EOF berbasis SVD digunakan untuk mereduksi matriks data ke dalam program komputer menggunakan software MATLAB. Reduksi dilakukan terhadap data curah hujan TRMM 3B42 wilayah cakupan Indonesia. Metode ini bertujuan untuk menentukan pola-pola dominan pada data curah baik secara spasial maupun temporal. Setelah itu digunakan metode FFT kembali pada pola temporal untuk menganalisis variasi diurnal.

\subsection{Jenis dan Sumber Data}

Data yang digunakan dalam penelitian ini adalah data curah hujan tropical rainfall measuring mission (TRMM) 3B42 yang diambil setiap 3 jam tahun 1999 dan data TRMM 3B43 yang diambil setiap bulan tahun 1998-2015. Data ini merupakan data global bulanan selama memiliki resolusi spasial $0.25^{\circ} \times 0.25^{\circ}$ dan resolusi temporal bulanan. Data TRMM 3B42 dan 3B43 ini disponsori oleh NASA (National Aeronautics and Space Administration) dan JAXA (Japan Aerospace Exploration Agency). Data ini berupa data digital compressed dengan format binary (bin) dan HDF. Reduksi data dan transformasi data dalam penelitian ini dilakukan sesuai dengan domain wilayah Indonesia.

\subsection{Langkah Penelitian}

Langkah-langkah yang dilakukan pada penelitian ini terdiri atas beberapa tahap. Tahap pertama adalah menyiapkan alat uji coba untuk menyusun suatu program menggunakan bahasa pemrograman MATLAB. Tahap kedua adalah mendeskripsikan dan mengektraksikan masing-masing data curah hujan TRMM 
3B42 dan 3B43 yang dibentuk dalam suatu matriks $X$ menggunakan fungsi-fungsi yang tersedia dalam software MATLAB. Tahap ketiga adalah menganalisis data TRMM 3B43 menggunakan metode transformasi Fourier. Pada tahap berikutnya hasil transformasi tersebut akan dianalisis untuk melihat sinyal curah hujan enam bulanan di Indonesia. Adapun tahap kelima adalah menganalisis EOF terhadap data curah hujan 3B42 di Indonesia menggunakan teknik SVD. Pada tahap analisis ini diuraikan teknik reduksi menggunakan metode EOF. Langkah terakhir adalah dengan menganalisis variasi diurnal yang terdapat pada data yang telah direduksi.

\subsubsection{Alat Uji}

Pada tahap ini, dilakukan langkah-langkah sebagai berikut:

1. Identifikasi masalah

Masalah pada penelitian ini adalah bagaimana penggunaan tarnsformasi Fourier untuk menganalisis sinyal curah hujan enam bulanan di Indonesia dan metode EOF berbasis SVD dalam menganalisis variabilitas curah hujan harian di Indonesia secara spasial dan temporal.

2. Penentuan tujuan

Tujuan dari penelitian ini adalah menganalisis sinyal curah hujan enam bulanan di Indonesia dan menganalisis variabilitas curah hujan harian di Indonesia secara spasial dan temporal menggunakan analisis EOF berbasis SVD.

3. Studi literatur

Studi literatur dilakukan dengan mengkaji karakteristik data TRMM 3B42 dan TRMM 3B43, mengkaji metode transformasi Fourier dan metode empirical orthogonal function (EOF) yang berbasis singular value decomposition (SVD).

4. Penyusunan algoritme

Setelah melakukan studi literatur, langkah selanjutnya adalah penyusunan algoritme untuk transformasi Fourier, reduksi data, dan menentukan mode EOF yang digunakan untuk analisis pola spasial dan temporal.

5. Penyusunan program komputer

Algoritme yang telah disusun kemudian diimplementasikan dalam salah satu bahasa pemograman komputer yaitu MATLAB. MATLAB dipilih karena fungsi-fungsi yang berkaitan dengan transformasi Fourier dan SVD telah tersedia dan siap digunakan. Setelah dijalankan, program yang disusun diharapkan menerima input berupa matriks data curah hujan wilayah 
cakupan Indonesia, program memberikan output berupa plot data spasial dan pola temporal.

\subsubsection{Ekstraksi Data}

Tahap ini adalah mengekstraksi data curah hujan TRMM 3B43 dan TRMM 3B42. Keda data tersebut merupakan data curah hujan berbentuk grid dalam skala global. Penelitian ini hanya difokuskan pada wilayah Indonesia, sehingga data perlu dipotong untuk menentukan variabel yang akan dianalisis agar hasil yang didapat lebih sesuai. Hal ini dilakukan agar data yang akan dihasilkan dapat mempermudah dalam menganalisis sinyal curah hujan pada suatu daerah. Matriks yang diperoleh adalah matriks data yang akan digunakan dalam penelitian.

\subsubsection{Transformasi Data TRMM 3B43 Menggunakan Transformasi Fourier}

Tahap ini adalah menerapkan metode transformasi Fourier pada data curah hujan TRMM 3B43 hasil ekstraksi data. Hasil dari metode memberikan suatu sinyal sinyal frekuensi terhadap periode curah hujan di Indonesia, yang kemudian diberikan beberapa plot yang menunjukkan perbedaan sinyal frekuensi curah hujan pada daerah.

\subsubsection{Reduksi Data TRMM 3B42 Menggunakan EOF Berbasis SVD}

Pada tahap ini akan diterapkan teknik EOF berbasis SVD terhadap matriks data curah hujan TRMM 3B42 hasil ekstraksi data. Hasil dari metode EOF berbasis SVD tersebut diberikan plot masing-masing mode EOF yang dihasilkan baik secara spasial dan temporal. Kemudian dilakukan analisis terhadap pola pola dominan secara spasial dan temporal.

\section{HASILDAN PEMBAHASAN}

\subsection{Eksplorasi Data}

Data yang diperoleh dari data TRMM 3B42 dan TRMM 3B43 merupakan data global untuk seluruh dunia. Oleh karena itu, perlu dilakukan ekstrasi data atau pemotongan data pada wilayah cakupan Indonesia untuk menganalisis data 
yang akan digunakan dalam penelitian. Berikut ini algoritme ekstraksi pada kedua data tersebut:

Algoritme 1 Ekstraksi Data TRMM 3B43

1. Penentuan domain wilayah Indonesia yang akan dianalisis yaitu $6^{0} \mathrm{LU}-$ $11^{0} \mathrm{LS}$ dan $95^{\circ} \mathrm{BT}-41^{0} \mathrm{BT}$.

2. Pembacaan data TRMM 3B43 yang memiliki format HDF. Hasil pembacaan data merupakan suatu vektor dengan panjang 691200.

3. Vektor tersebut kemudian disusun dalam bentuk matriks berukuran $1440 \times 440$ untuk mendapatkan matriks data curah hujan dunia.

4. Matriks tersebut kemudian dipotong untuk memperoleh data wilayah Indonesia.

5. Matriks data curah hujan Indonesia tersebut kemudian untuk setiap data bulanan disusun berdasarkan variabel waktu untuk memperoleh matriks $X$ data baru yang nantinya akan dianalisis menggunakan Transformsi Fourier.

Algoritme 2 Ekstraksi Data TRMM 3B42

1. Penentuan domain wilayah Indonesia yang akan dianalisis yaitu $6^{0} \mathrm{LU}$ $11^{0} \mathrm{LS}$ dan $95^{\circ} \mathrm{BT}-41^{0} \mathrm{BT}$.

2. Pembacaan data TRMM 3B42 yang memiliki format binary. Hasil pembacaan data merupakan suatu vektor dengan panjang 576000.

3. Vektor tersebut kemudian disusun dalam bentuk matriks berukuran $1440 \times 400$ untuk mendapatkan matriks data curah hujan dunia.

4. Matriks tersebut kemudian dipotong untuk memperoleh data wilayah Indonesia.

5. Matriks data curah hujan Indonesia tersebut kemudian disusun menjadi matriks satu kolom yang kemudian digabungkan dengan setiap data untuk 3 jam selanjutnya menjadi matriks $Y$ dengan baris menyatakan variabel ruang, sedangkan kolom menyatakan variabel waktu.

6. Matriks $Y$ tersebut merupakan matriks yang akan direduksi menggunakan EOF.

Eksplorasi data diawali dengan menyajikan pola data yang tersedia dalam bentuk visual berdasarkan grid data global. Ukuran grid data dengan koordinat tersebut yaitu $1440 \times 400$. Selanjutnya dilakukan proses pemotongan data sesuai dengan domain wilayah Indonesia yaitu $6^{0} \mathrm{LU}-11^{0} \mathrm{LS}$ dan $95^{\circ} \mathrm{BT}-141^{0} \mathrm{BT}$, sehingga untuk setiap satu bulan diperoleh matriks data berukuran $119 \times 236$ untuk data TRMM 3B43 dan matriks data berukuran 73 x 201 untuk data TRMM 3B42.

\subsection{Analisis Transformasi Fourier}


Matriks data $X$ yang kita peroleh dari dasil ekstraksi data merupakan matriks yang berorientasi dengan ruang dan waktu, dengan baris dan kolom menyatakan suatu posisi dari lokasi pengambilan data. Data tersebut kemudian diolah menggunakan transformasi Fourier untuk mendapatkan informasi kemungkinan potensi periode hujan enam bulanan di wilayah Indonesia. Periode hujan tersebut dianalisis menggunakan tiga parameter, yaitu: periode curah hujan enam bulanan di seluruh Indonesia, perbandingan periode hujan enam bulanan dengan luas keseluruan sinyal, dan perbandingan periode hujan enam bulanan dengan periode dua belas bulanan. Algoritme yang digunakan merupakan FFT yang telah tersedia pada Matlab dengan tahapan di bawah ini.

Algoritme 3 Analisis Transformasi Fourier

1. Menentukan frekuensi contoh.

2. Menentukan periode contoh.

3. Mentukan panjang sinyal yang digunakan.

4. Membuat vektor waktu yang berdasarkan panjang sinyal dan periode.

5. Memroses data menggunakan fungsi FFT yang tersedia di Matlab.

6. Mengolah dan menganalisis hasil dari FFT.

\section{A. Tipe Monsoonal}

Banten

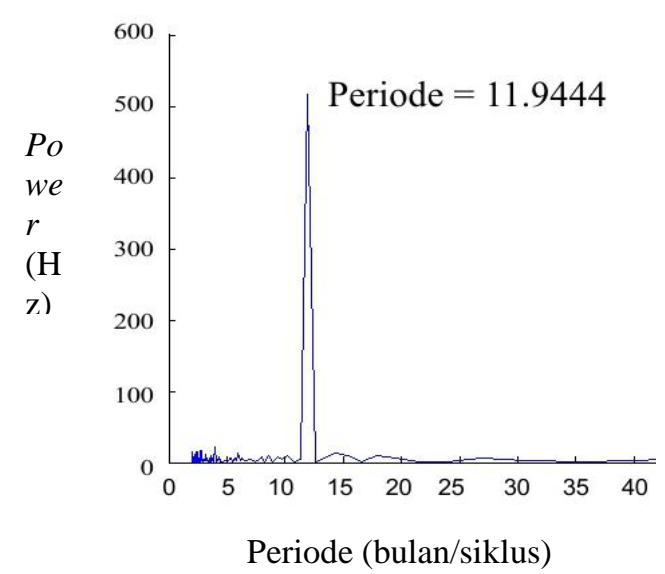

Jawa Tengah

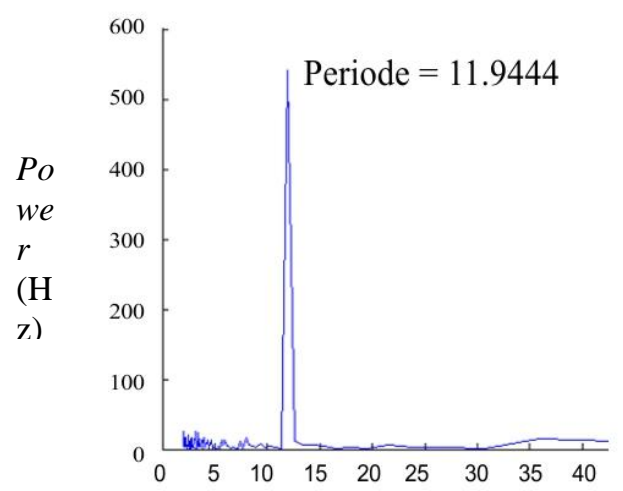

Jawa Barat

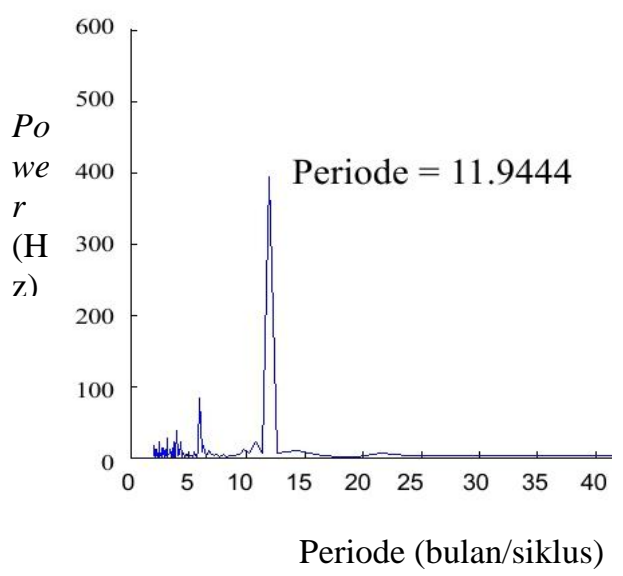

NTT

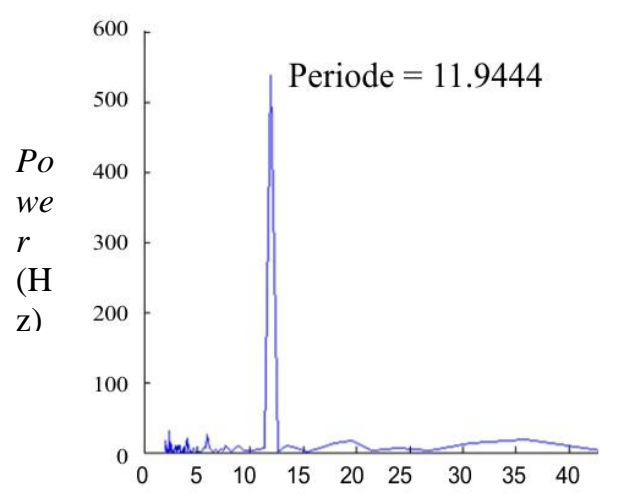




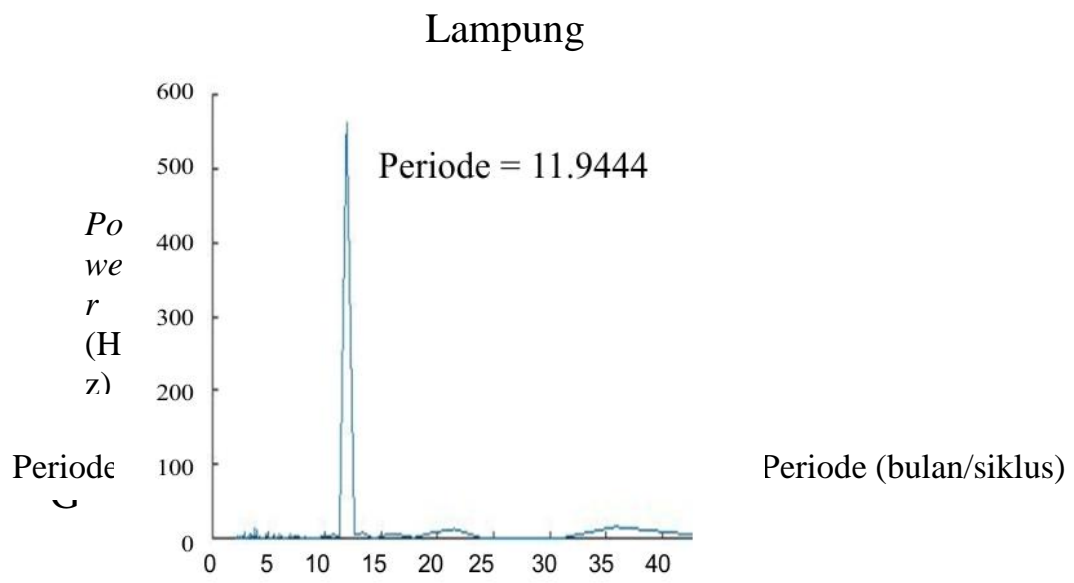

ambar 1 Grafik Periode Periode (bulan/siklus) ah Monsoon

Pada daerah monsoonal nilai maksimum global dari hasil FFT berada pada periode 11,9444 bulan atau mendekati dua belas bulan. Terdapat beberapa nilai maksimum grafik salah satunya periode enam bulan, namun memiliki nilai sinyal yang jauh di bawah dari power pada periode 11,9444 bulan. Hal ini menunjukkan bahwa pada daerah monsoonal periode curah hujan yang dominan adalah periode 12 bulan, sedangkan periode yang lain tidak terlalu berpengaruh pada periode hujan di daerah tersebut. Analisis lengkap hasil terhadap paramater yang digunakan untuk mengetahui seberapa besar potensi periode enam bulan pada beberapa daerah monsoonal adalah sebagai berikut:

Tabel 1 Kekuatan (Power) sinyal 6 bulan di daerah monsoon

\begin{tabular}{lc}
\hline Provinsi & Pengaruh periode 6 bulan \\
\hline Banten & 38.07 \\
Jawa Barat & 36.69 \\
Jawa Tengah & 21.98 \\
Nusa Tenggara Timur & 0.1398 \\
Lampung & 7.877 \\
\hline
\end{tabular}

Tabel 2 Pengaruh sinyal 6 bulan terhadap luas keseluruhan (Riemann) sinyal di daerah monsoon

\begin{tabular}{lc}
\hline Provinsi & Pengaruh periode 6 bulan \\
\hline Banten & 0.0332
\end{tabular}




$\begin{array}{ll}\text { Jawa Barat } & 0.0072 \\ \text { Jawa Tengah } & 0.0145 \\ \text { Nusa Tenggara Timur } & 0.0002 \\ \text { Lampung } & 0.0087\end{array}$

Tabel 3 Pengaruh sinyal 6 bulan terhadap sinyal 12 bulan di daerah monsoon

\begin{tabular}{lc}
\hline Provinsi & Pengaruh periode 6 bulan \\
\hline Banten & 0.0139 \\
Jawa Barat & 0.0714 \\
Jawa Tengah & 0.0280 \\
Nusa Tenggara Timur & 0.0008 \\
Lampung & 0.0263 \\
\hline
\end{tabular}

B. Tipe Ekuatorial
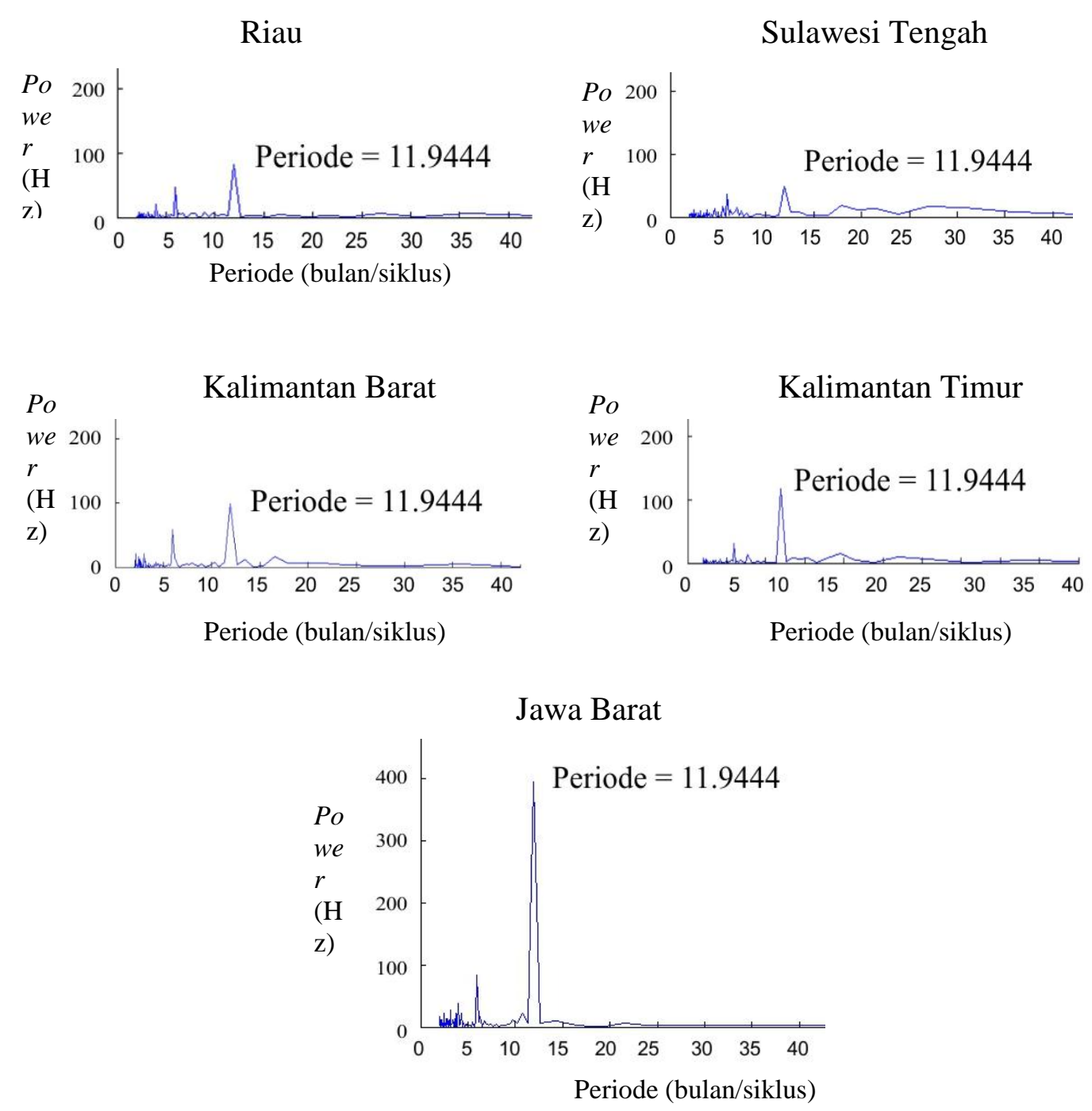
Gambar 2 Grafik Periode Curah Hujan di Daerah Ekuatorial

Pada daerah ekuatorial nilai maksimum global berada pada periode 11,9444 bulan atau mendekati dua belas bulan, akan tetapi pada periode enam bulan memiliki nilai yang mendekati nilai ketika periode dua belas bulan. Hal ini menunjukkan bahwa pada daerah tipe ekuatorial terdapat dua periode hujan yang dominan yaitu periode enam bulan dan dua belas bulan. Hasil lengkap analisis terhadap paramater yang digunakan sebagai berikut:

Tabel 4 Kekuatan (Power) sinyal 6 bulan di daerah ekuatorial

\begin{tabular}{lc}
\hline Provinsi & Pengaruh periode 6 bulan \\
\hline Aceh & 75.09 \\
Riau & 43.29 \\
Kalimantan Barat & 79.80 \\
Kalimantan Timur & 20.97 \\
Sulawesi Tengah & 41.98 \\
\hline
\end{tabular}

Tabel 5 Pengaruh sinyal 6 bulan terhadap luas keseluruhan (Riemann) di daerah ekuatorial

\begin{tabular}{lc}
\hline Provinsi & Pengaruh periode 6 bulan \\
\hline Aceh & 0.1442 \\
Riau & 0.0529 \\
Kalimantan Barat & 0.0839 \\
Kalimantan Timur & 0.0243 \\
Sulawesi Tengah & 0.0771 \\
\hline
\end{tabular}

Tabel 6 Pengaruh sinyal 6 bulan terhadap sinyal 12 bulan di daerah ekuatorial

\begin{tabular}{lc}
\hline Provinsi & Pengaruh periode 6 bulan \\
\hline Aceh & 0.7233 \\
Riau & 0.6761 \\
Kalimantan Barat & 0.9691
\end{tabular}




$\begin{array}{ll}\text { Kalimantan Timur } & 0.4120 \\ \text { Sulawesi Tengah } & 0.8528\end{array}$

C. Tipe Lokal
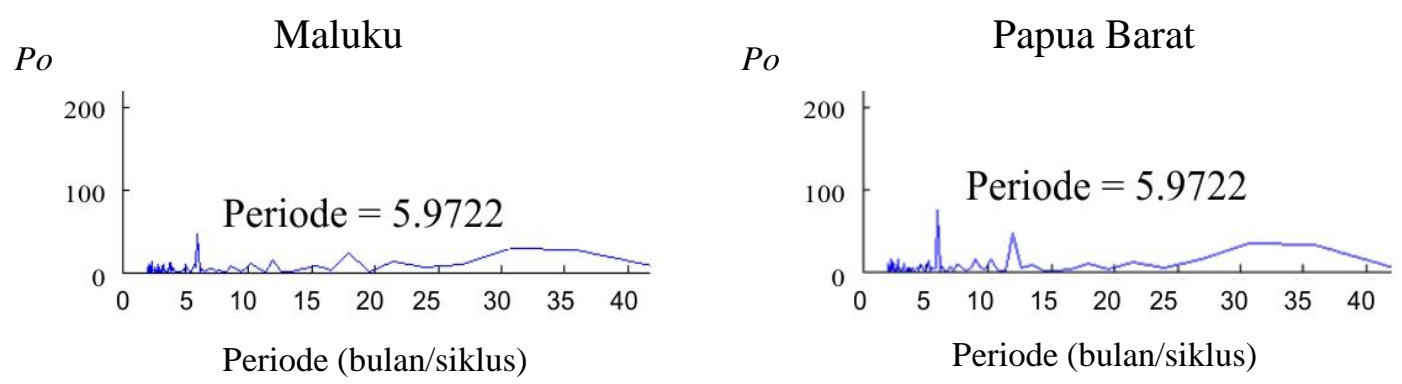

Gambar 3 Grafik Periode Curah Hujan di Daerah Lokal

Pada daerah dengan tipe lokal memiliki nilai maksimum global terdapat pada periode 5,972 bulan atau mendekati enam bulan. Selain itu terdapat beberapa nilai yang mendekati nilai maksimum grafik. Hal ini menunjukkan bahwa pada daerah dengan tipe lokal curah hujannya lebih dipengaruhi oleh kondisi dari lingkungannya, sehingga terdapat beberapa pola curah hujan yang dominan pada daerah-daerah tersebut. Hasil lengkap analisis terhadap parameter yang digunakan sebagai berikut:

Tabel 7 Kekuatan (Power) periode 6 bulan di daerah lokal

\begin{tabular}{lc}
\hline Provinsi & Pengaruh periode 6 bulan \\
\hline Maluku & 59.1514 \\
Papua Barat & 36.02 \\
\hline \multicolumn{2}{c}{ Tabel 8 Pengaruh sinyal 6 bulan terhadap luas keseluruhan } \\
\multicolumn{2}{c}{ (Riemann) di daerah lokal } \\
\hline Provinsi & Pengaruh periode 6 bulan \\
\hline Maluku & 0.0100 \\
Papua Barat & 0.0056 \\
\hline
\end{tabular}

Tabel 9 Pengaruh sinyal6 bulan terhadap sinyal 12 bulan

\begin{tabular}{ll}
\hline Provinsi & Pengaruh periode 6 bulan \\
\hline
\end{tabular}




\begin{tabular}{ll}
\hline Maluku & 1.4285 \\
Papua Barat & 1.2162 \\
\hline
\end{tabular}

A. Pengaruh periode hujan enam bulanan di Indonesia

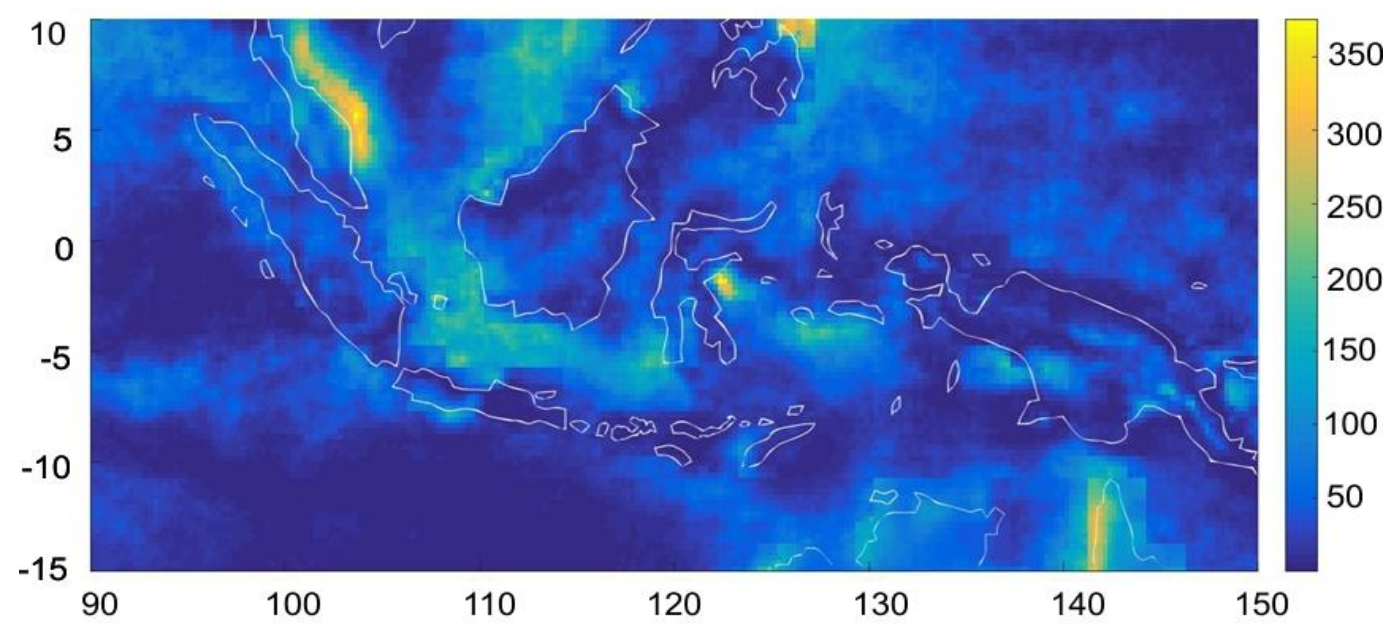

Gambar 4 Peta wilayah Indonesia dengan periode curah hujan 6 bulan

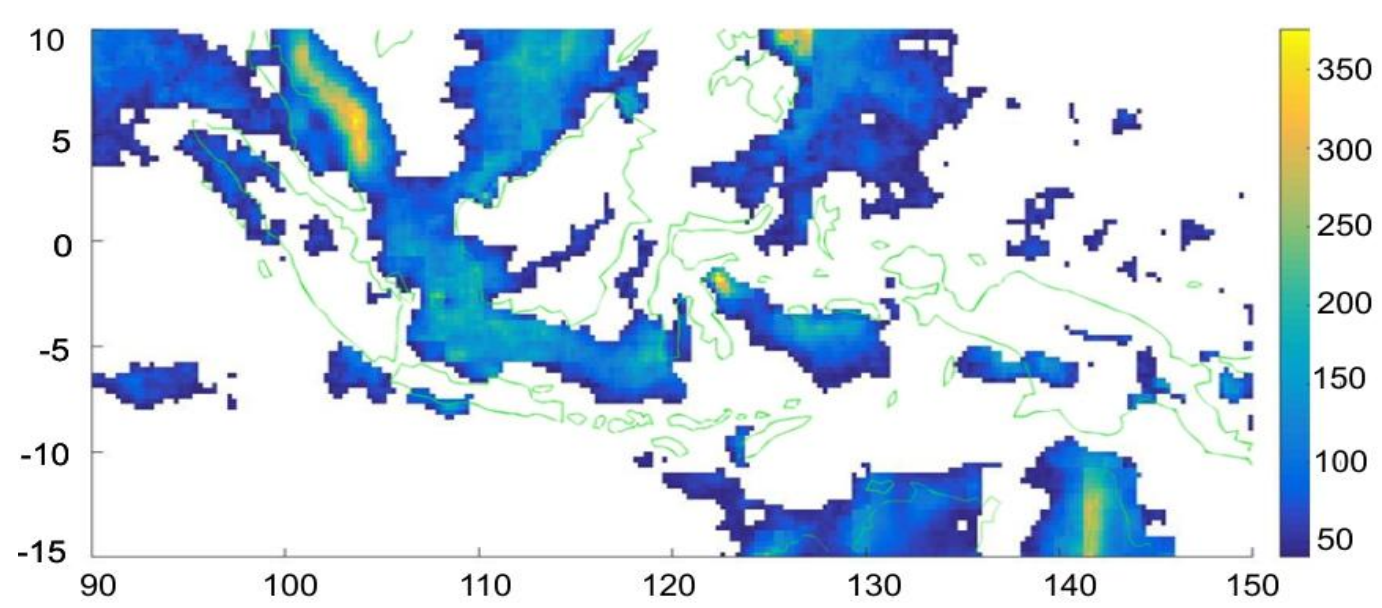

Gambar 5 Peta wilayah Indonesia dengan periode curah hujan 6 bulan yang nilai frekuensi sinyalnya lebih dari 40

Peta di atas menggambarkan wilayah di Indonesia yang memiliki curah hujan dengan periode enam bulan, dengan warna menunjukkan kekuatan sinyalnya. Secara umum seluruh wilayah Indonesia mempunyai periode curah 
hujan enam bulanan dengan kekuatan sinyal yang berbeda-beda. Kemudian dilakukan filter terhadap nilai signal frekuensi curah hujan yaitu dengan menghilangkan nilai yang kurang dari 40 dalam skala warna peta 0 hingga 350 . Terlihat bahwa sinyal kuat periode enam bulanan terdapat di lautan, namun ada beberapa didaratan Indonesia, seperti: Aceh, Riau Kalimantan Barat, dan Maluku.

B. Perbandingan periode hujan enam bulan terhadap luas keseluruhan sinyal.

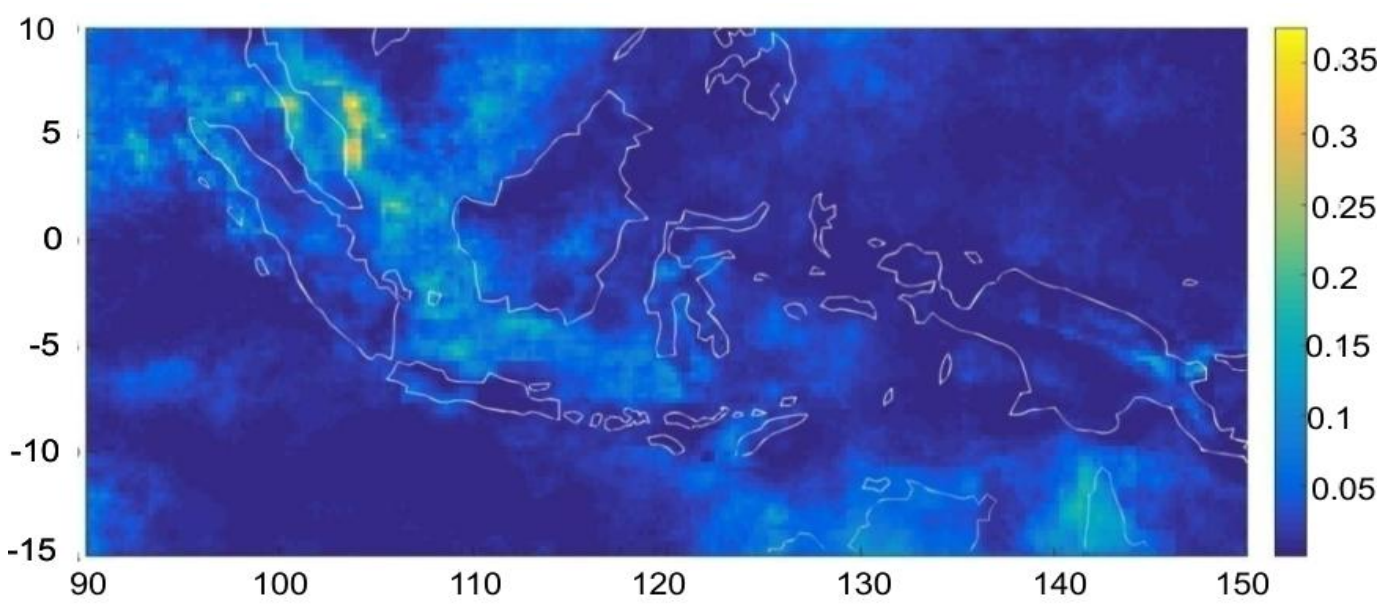

Gambar 6 Peta pengaruh periode curah hujan 6 bulan terhadap luas keseluruhan (Riemann) sinyal

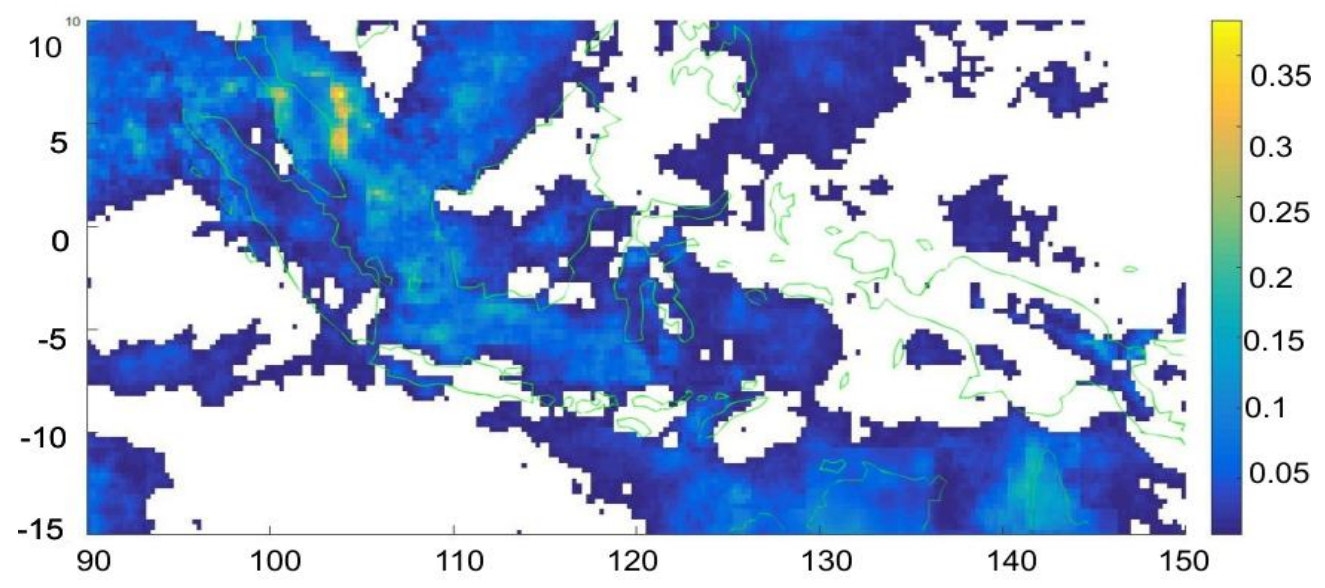

Gambar 7 Peta pengaruh periode curah hujan 6 bulan dengan luas keseluruhan (Riemann) sinyal nilainya lebih dari 0.03

Peta di atas menggambarkan pengaruh curah hujan periode enam bulanan terhadap keseluruhan signal frekuensi di seluruh periode frekuensi (Riemann), dengan warna menunjukkan kekuatan sinyalnya. Hal ini dilakukan untuk mengetahui pengaruh signal pada periode enam bulanan terhadap keseluruhan 
kekuatan signal pada periode hujan suatu wilayah. Kemudian dilakukan filter terhadap nilai signal frekuensi curah hujan enam bulanan yaitu dengan menghilangkan nilai yang kurang dari 0.03 dalam skala warna peta 0 hingga 0.35 . Terlihat bahwa kebanyakan sinyal kuat periode enam bulanan terjadi di daerah lautan, sedangkan hanya pada beberapa daratan yang memiliki sinyal yang kuat seperti: Sumatera, Kalimantan, dan Sulawesi.

C. Pengaruh periode hujan enam bulan terhadap periode dua belas bulan

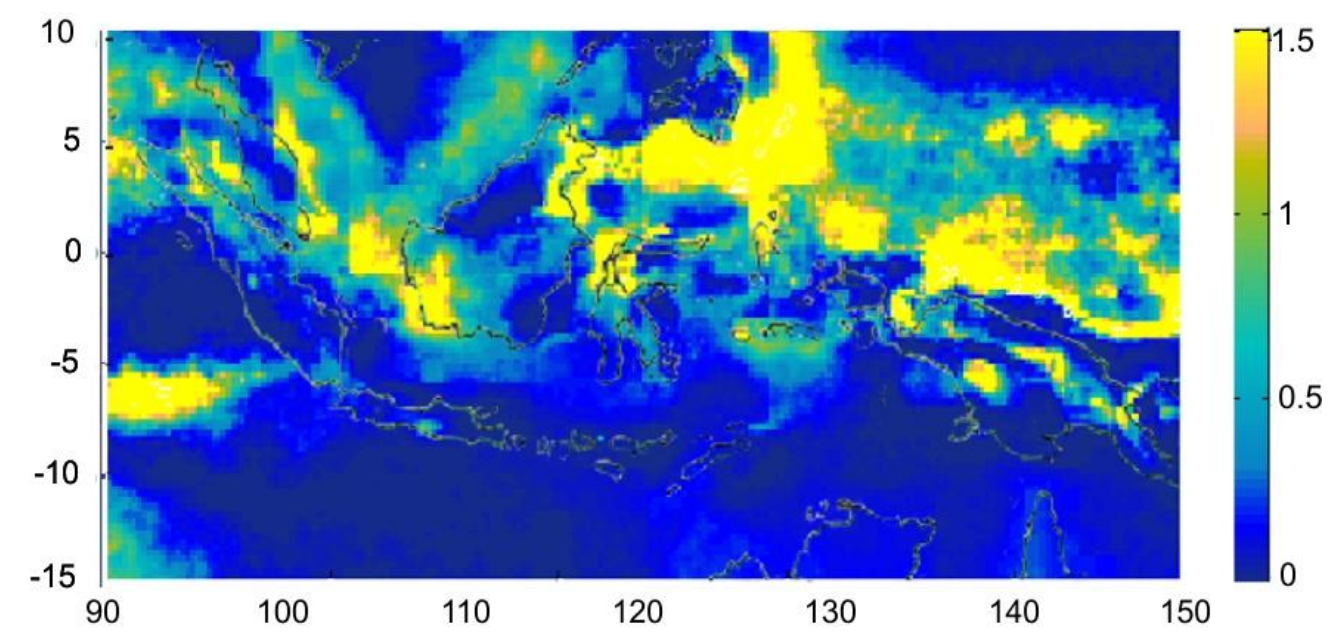

Gambar 8 Peta pengaruh periode curah hujan 6 bulan terhadap periode 12 bulan di wilayah Indonesia

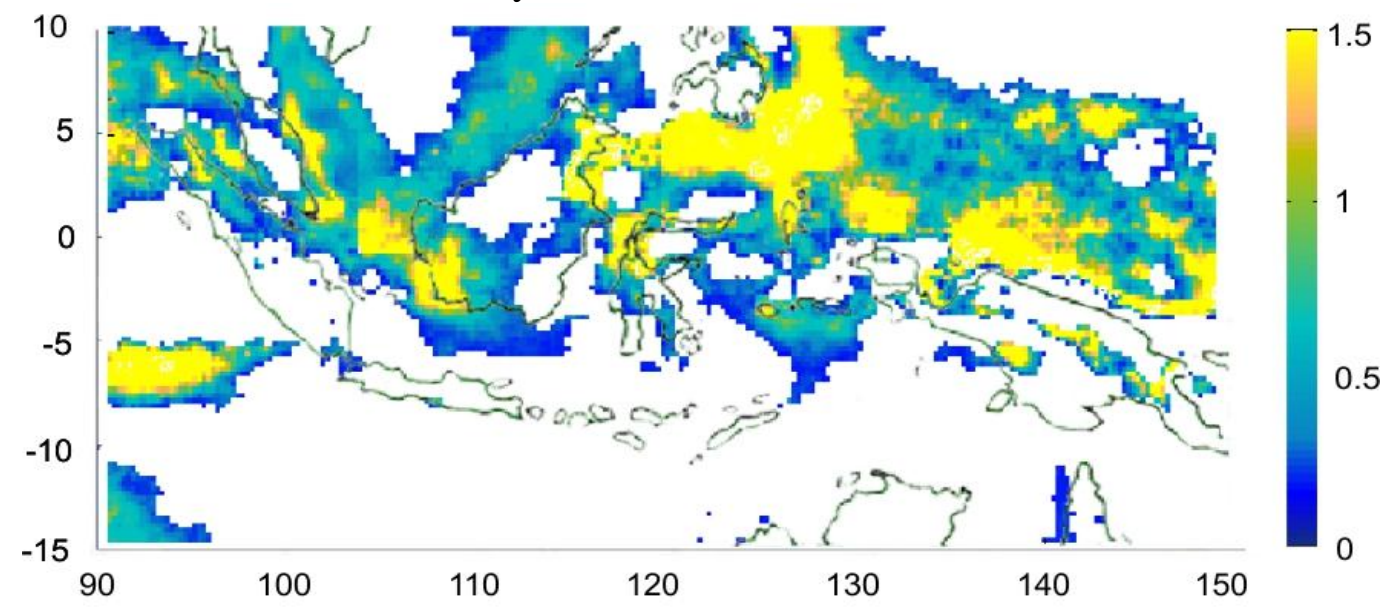

Gambar 9 Peta pengaruh periode curah hujan 6 bulan terhadap periode 12 bulan yang nilainya lebih dari 0.1

Peta di atas menggambarkan pengaruh curah hujan periode enam bulanan terhadap periode dua belas bulanan secara langsung, dengan warna menunjukkan kekuatan sinyalnya. Hal ini dilakukan untuk mengetahui pengaruh periode enam bulanan dengan periode hujan yang memiliki signal frekuensi paling kuat di 
beberapa daerah Indonesia, yaitu periode dua belas bulanan. Kemudian dilakukan filter terhadap nilai signal frekuensi curah hujan enam bulanan yaitu dengan menghilangkan nilai yang kurang dari 0.1 dalam skala warna peta 0 hingga 1.5. Diperoleh bahwa sinyal kuat periode enam bulanan terdapat di wilayah lautan, namun ada beberapa didaratan Indonesia, seperti: Aceh, Riau Kalimantan Barat, Sulawesi Tengah, dan Maluku yang sinyal curah hujan 6 bulanan pada daerah tersebut sangat kuat.

\subsection{Analisis Empirical Orthogonal Function (EOF)}

Metode EOF merupakan metode yang digunakan untuk mencari pola-pola dominan pada suatu data yang berevolusi pada pola ruang dan waktu. Metode EOF yang digunakan dalam penelitian ini adalah metode EOF berbasis singular value decompotition (SVD) untuk memperoleh pola dominan terhadap ruang dan waktu matriks data curah hujan setiap 3 jam. Tahapan dari analisis metode EOF terhadap matriks data akan disajikan di bawah ini.

Algoritme 4 analisis EOF

1. Diberikan matriks data.

2. Normalisasi matriks data.

3. Pereduksian matriks data dengan SVD data $=U \Sigma V^{T}$.

4. Penentuan nilai singular dari yang terbesar.

5. Analisis data secara spasial dan temporal terhadap mode EOF dominan.

Mode EOF yang diperoleh merupakan nilai yang menunjukkan ukuran kontribusi dari setiap komponen utama terhadap masing-masing pengamatan. Nilai mode EOF tersebut dapat berupa bilangan positif maupun negatif. Semakin besar nilai dari mode EOF, semakin besar pula kontribusi dari komponen tersebut terhadap pengamatan. Dalam penelitian ini nilai mode EOF diperoleh dari nilai perkalian matriks $U$ dan $\Sigma$ dari hasil SVD dari matriks data. Vektor singular mendeskripsikan hubungan dari daerah-daerah yang memiliki curah hujan di atas rata-rata. Daerah dengan nilai unsur vektor positif menunjukkan bahwa daerah tersebut memiliki curah hujan di atas rata-rata, sedangkan nilai negatif menunjukkan curah hujan di bawah rata-rata. Hasil analisis menghasilkan 2920 mode EOF dari matriks data.

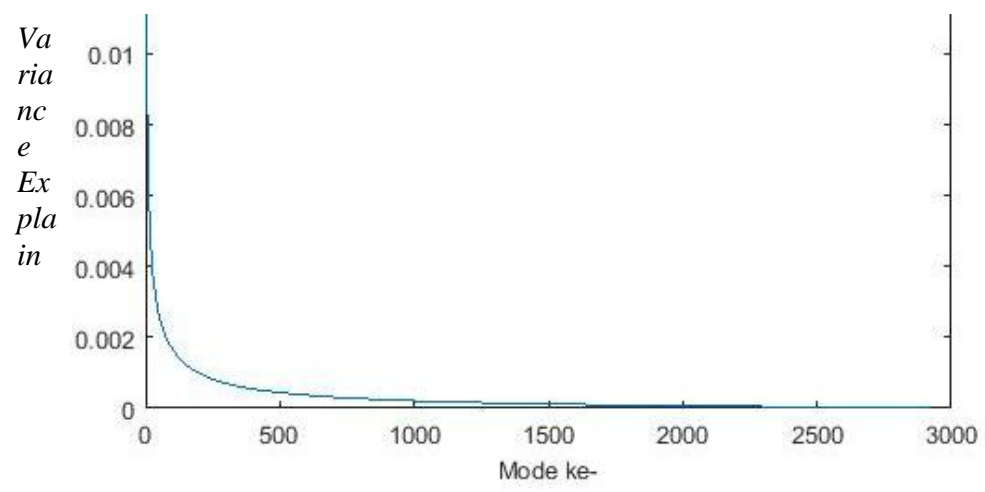


Gambar 10 Variance explain (pengaruh) setiap mode EOF terhadap matriks data.

Pada penelitian ini akan dianalisis 3 nilai singular yang terbesar yang menunjukkan kontribusi paling besar terhadap curah hujan harian di Indonesia. Analisis dilakukuan terhadap pola spasial dan temporal. Pola spasial merupakan hasil visualisasi dari skor komponen utama dari masing-masing mode EOF, sedangkan pola temporal dalam penelitian ini diolah lagi menggunakan metode FFT agar menunjukkan periode hujan terdapat pada mode EOF dominan.

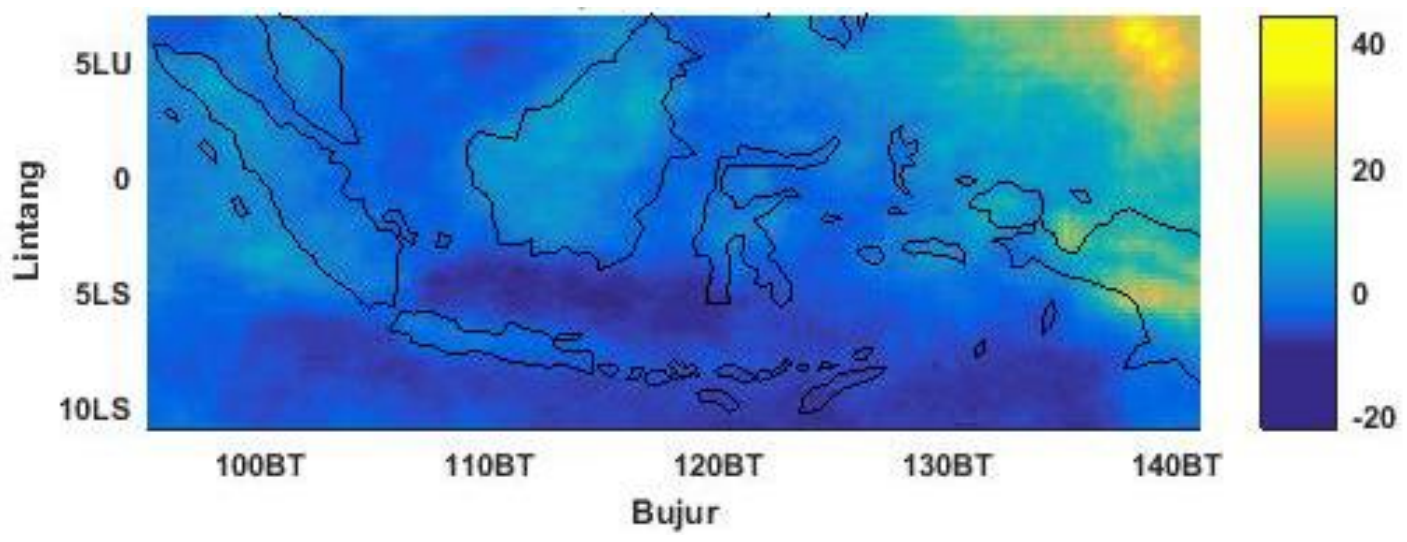

Gambar 11 Pola spasial curah hujan Indonesia pada mode EOF 1.

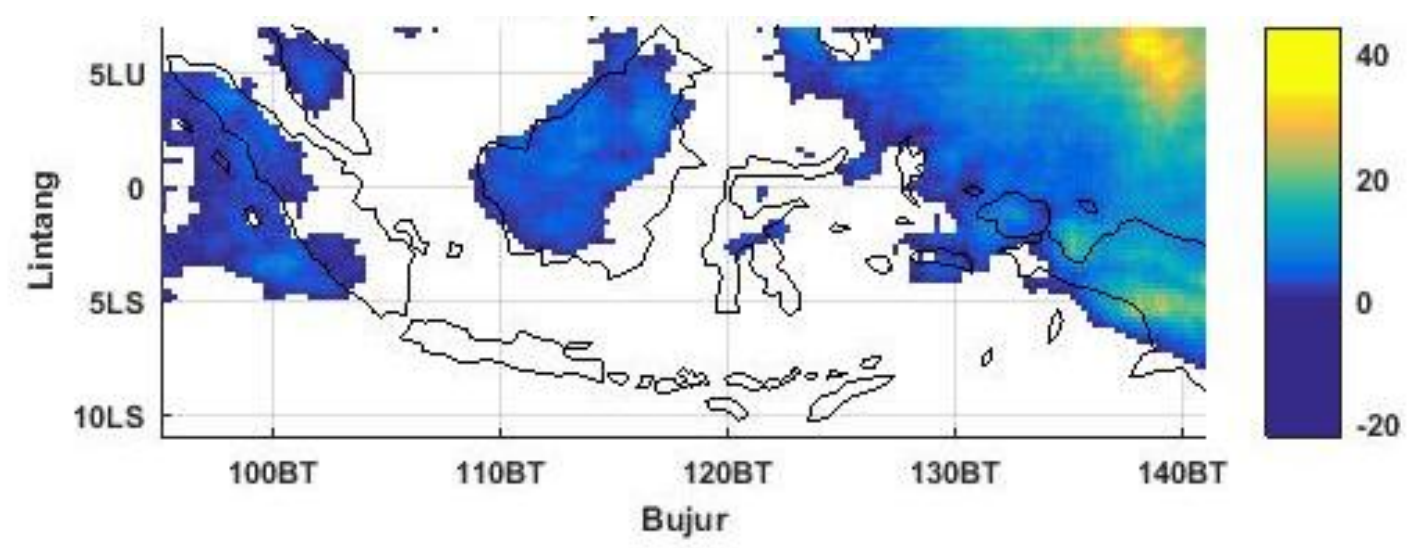

Gambar 12 Pola spasial curah hujan Indonesia mode EOF 1 yang di atas rata-rata.

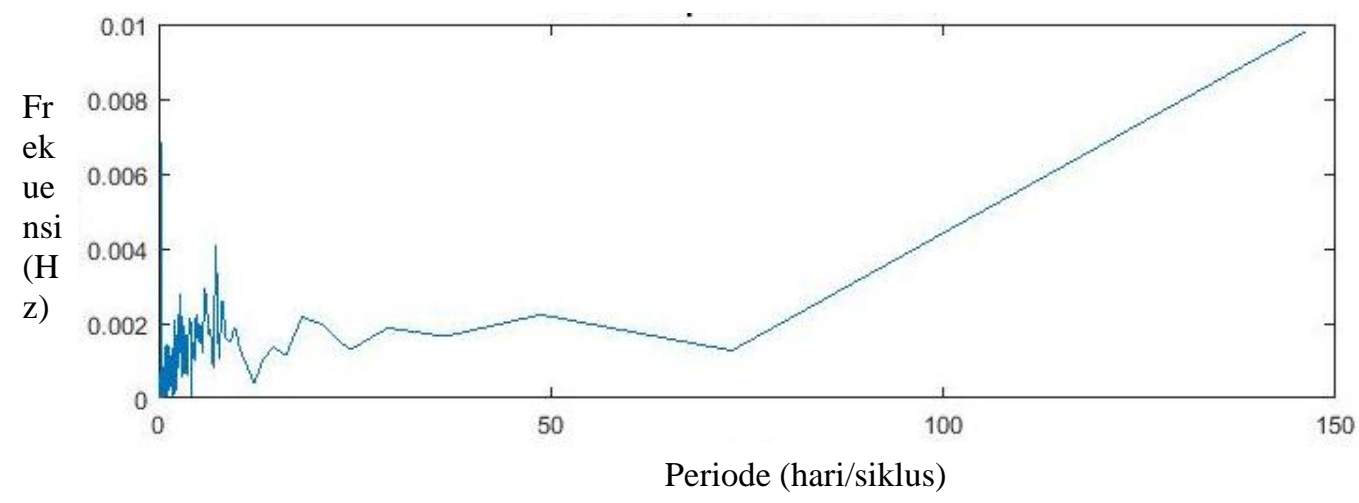


Gambar 13 Pola temporal (periode) curah hujan Indonesia Mode EOF 1.

Pola spasial mode EOF merupakan hasil visualisasi dari skor komponen utamanya. Varian yang dapat dijelaskan mode 1 terhadap data yang telah direduksi dengan pengambilan 6 skor utama adalah 19.8861\%. Curah hujan pada mode ini pada data yang telah dinormalisasi berkisar antara -10 sampai 35. Pada Gambar 11 dilakukan filter untuk data di bawah rata-rata untuk memperjelas pengamatan. Wilayah yang memiliki curah hujan tinggi berada di sekitar Aceh, Kalimantan Barat, Sulawesi Tengah, dan Papua. Diperoleh bahwa Gambar 11 merupakan grafik curah hujan 6 bulanan daerah Indonesia dengan tipe ekuatorial dan lokal. Dari pembahasan sebelumnya, diperoleh bahwa tipe ekuatorial dan tipe lokal memiliki sinyal curah hujan 6 bulanan yang tinggi.

Hal ini semakin diperkuat dari Gambar 12 yang merupakan grafik pola temporal hasil FFT dari vektor singular yang berkaitan dengan mode EOF 1, yang menunjukan bahwa yang paling dominan adalah periode hujan dari 150-180 hari yaitu sekitar 6 bulan, sehingga dapat diperoleh hasil bahwa mode EOF 1 merupakan pola yang dipengaruhi pola hujan 6 bulanan. 


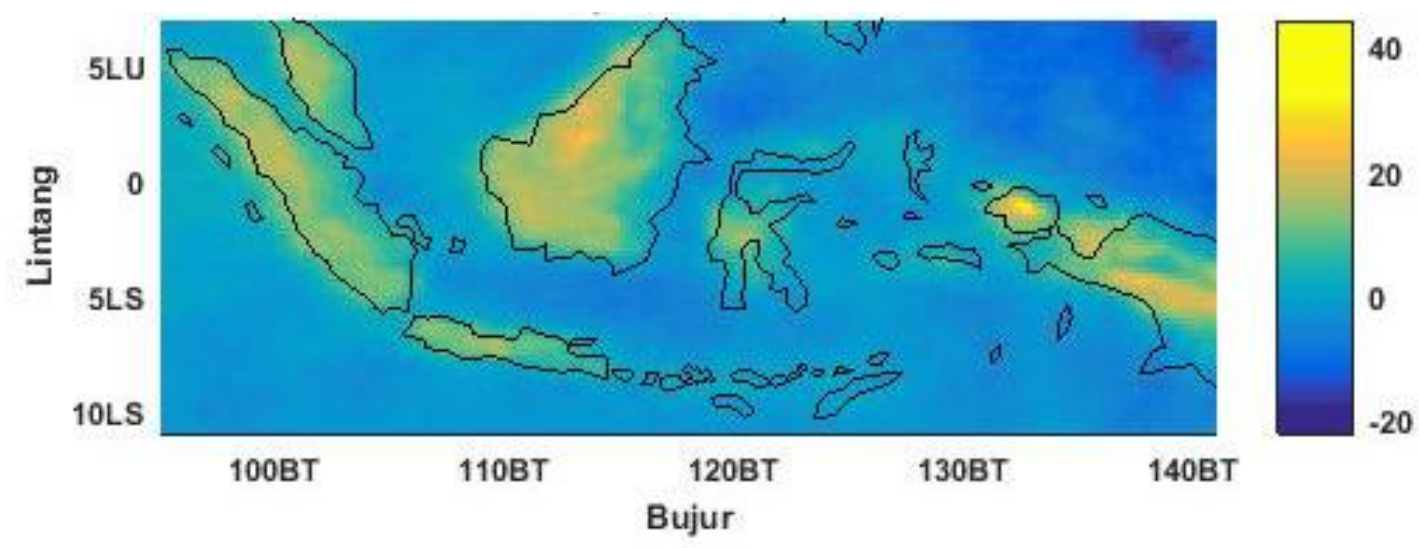

Gambar 14 Pola spasial curah hujan Indonesia mode EOF 2.

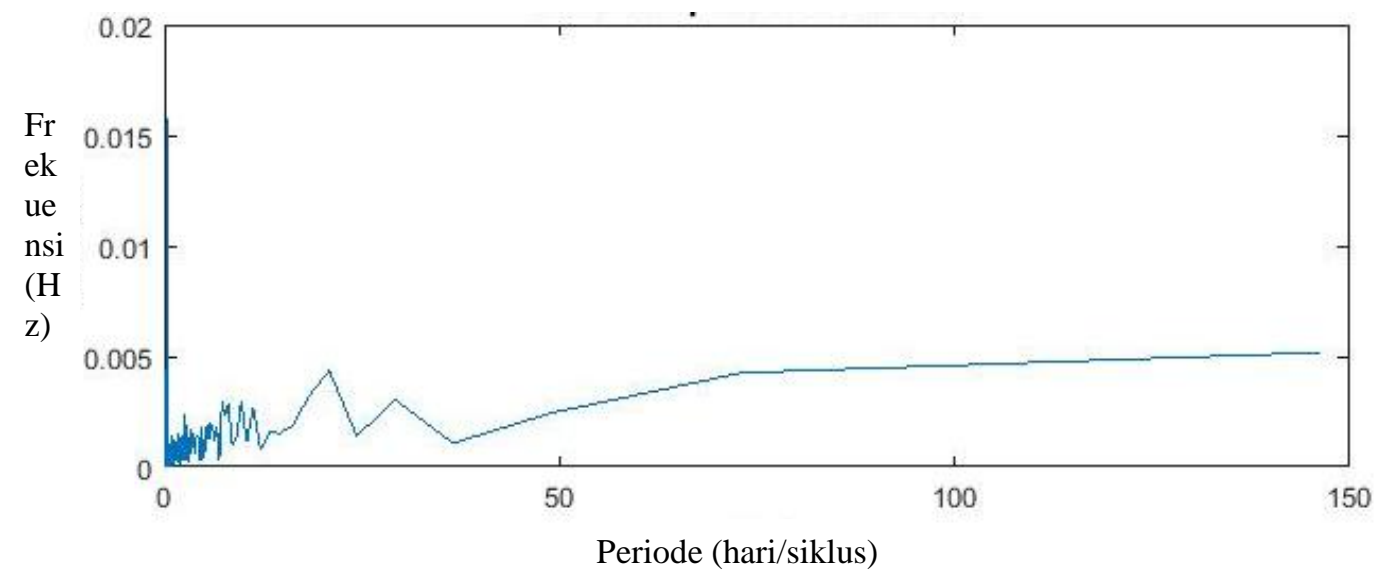

Gambar 15 Pola temporal (periode) curah hujan Indonesia mode EOF 2.

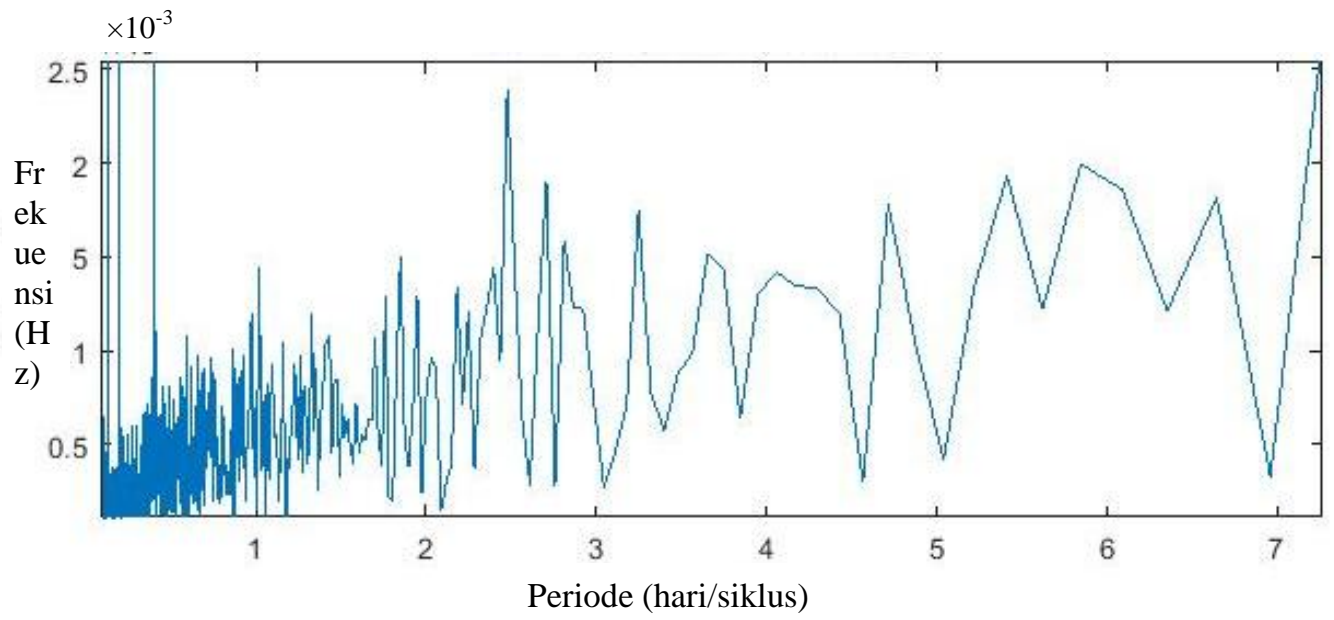

Gambar 16 Pola temporal (periode) mode curah hujan Indonesia EOF 2 periode $0-7$ hari. 
Mode EOF 2 pada Gambar 14 menunjukkan bahwa setiap wilayah darat di Indonesia memiliki curah hujan yang tinggi dalam 1 pola dominan yang sama. Curah hujan pada mode ke 2 pada data yang telah dinormalisasi berkisar antara 20 sampai 30. Sebaliknya, curah hujan yang di bawah rata-rata terjadi di setiap perairan di Indonesia. Pada Gambar 15 dan 16 menunjukkan grafik vektor singular mode 2 yang telah di FFT. Pada Gambar 16 skala sumbu mendatar diperkecil antara 0 sampai 7 untuk menganalisis variasi diurnal yang muncul. Diperoleh bahwa terdapat kontribusi variasi diurnal pada mode 2 yang ditunjukkan oleh periode hujan 1 hari pada Gambar 15 meskipun kontribusinya cukup kecil dalam keseluruhan sinyal. Mode 2 dapat menjelaskan varian terhadap hasil reduksi data reduksi data dari pengambilan 6 skor utama sebesar $18.7360 \%$.

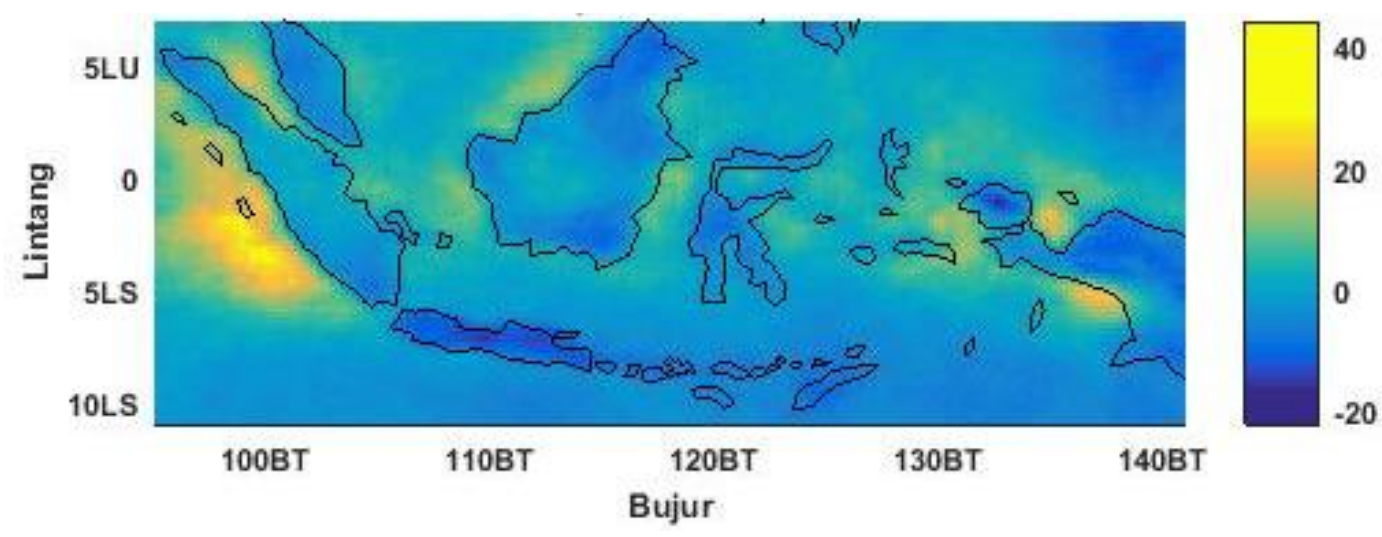

Gambar 17 Pola spasial curah hujan Indonesia mode EOF 3

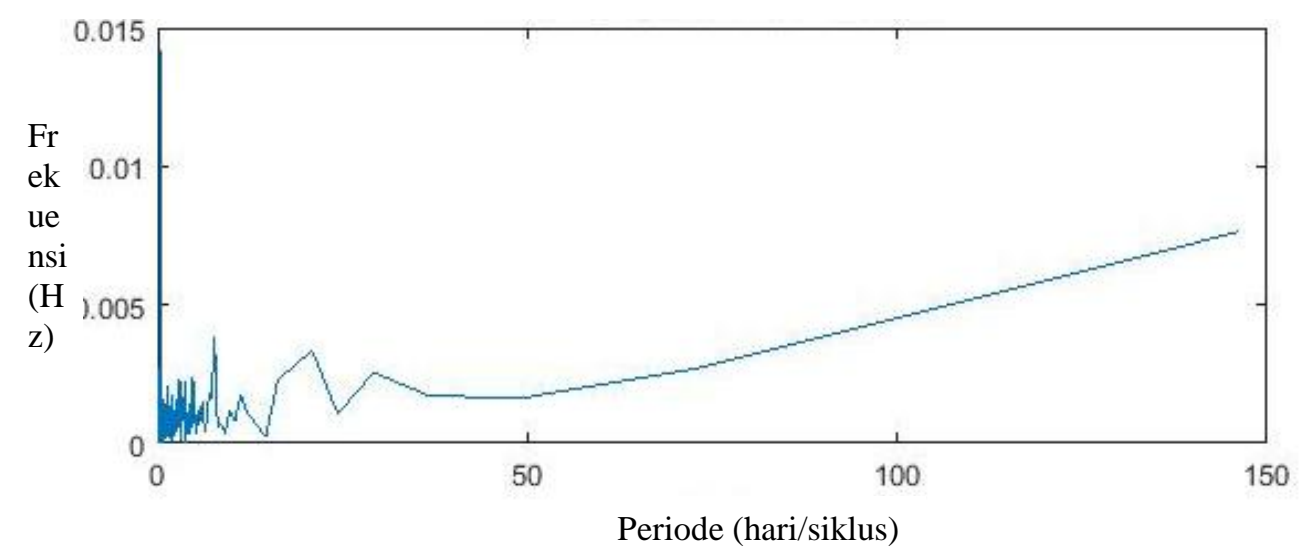

Gambar 18 Pola temporal (periode) curah hujan Indonesia mode EOF 3 


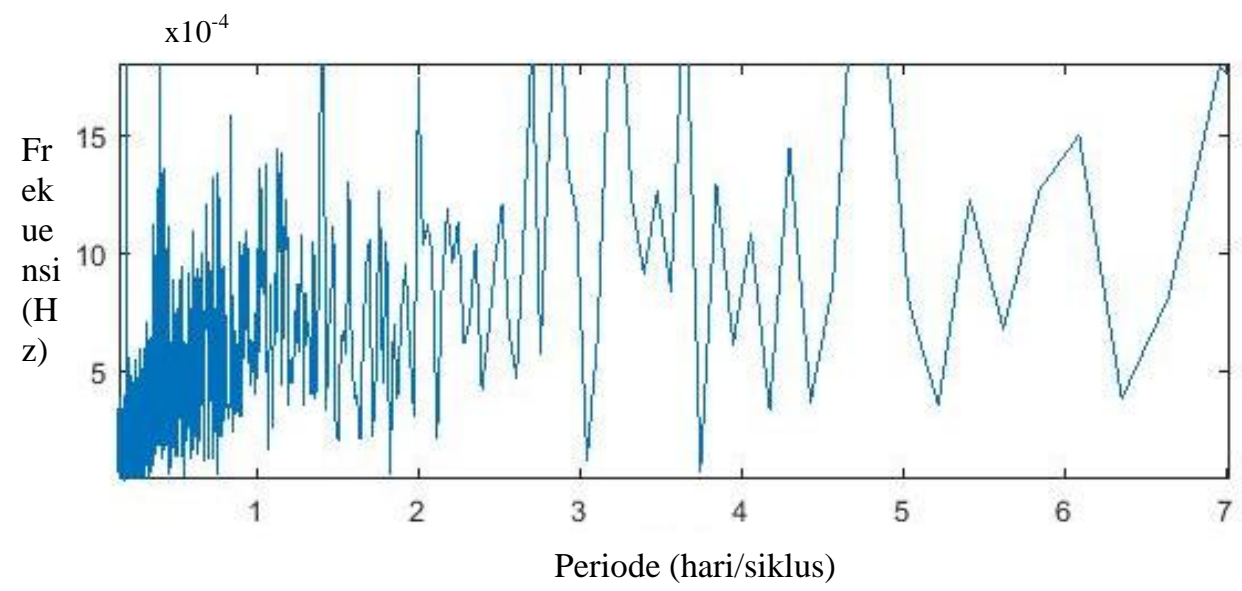

Gambar 19 Pola temporal (periode) curah hujan Indonesia mode EOF 3 periode $0-7$ hari

Gambar 17 menunjukkan pola spasial mode ke 3 EOF. Pola spasial mode ke 3 menunjukkan bahwa setiap wilayah perairan di Indonesia memiliki curah hujan yang tinggi dalam 1 pola dominan yang sama. Hal ini berkebalikan dengan pola pada mode EOF 2. Curah hujan mode ke 3 pada data yang telah dinormalisasi berkisar antara -20 sampai 30. Pola temporal dari mode 3 ditunjukkan pada Gambar 18 dan 19 menunjukkan grafik vektor singular mode 2 yang telah di FFT. Pada Gambar 18 skala sumbu mendatar diperkecil antara 0 sampai 7 untuk menganalisis variasi diurnal yang muncul. Dapat diperoleh bahwa terdapat kontribusi variasi diurnal pada mode 3 yang ditunjukkan oleh periode hujan 1 hari pada Gambar 15 meskipun kontribusinya cukup kecil dalam keseluruhan sinyal. Mode 3 dapat menjelaskan varian terhadap hasil reduksi data dari pengambilan 6 skor utama sebesar $16.8848 \%$.

\section{SIMPULAN}

Analisis FFT pada data TRMM 3B43 menghasilkan sinyal curah hujan 6 bulanan dan 12 bulanan. Wilayah Indonesia yang terbagi menjadi 3 tipe hujan yatiu monsoonal, ekuatorial, dan lokal memiliki kekuatan sinyal curah hujan 6 bulanan yang berbeda-beda. Tipe hujan monsoonal memiliki sinyal curah hujan 6 bulanan yang relatif sangat kecil, sehingga tidak berpengaruh terhadap sinyal periode hujan secara keseluruhan. Tipe hujan ekuatorial memiliki sinyal curah hujan 6 bulanan yang relatif tinggi terhadap sinyal 12 bulanan, namun tidak melebihi kekuatan sinyal 12 bulanan. Tipe lokal memiliki sinyal curah hujan 6 bulanan yang sangat tinggi dan mondominasi curah hujan 12 bulan.

Penerapan metode EOF berbasis SVD pada data TRMM 3 B42 menghasilkan beberapa mode EOF. Analisis EOF berbasis SVD pada data TRMM 3B42 dilakukan pada 3 mode dominan. Mode 1 menghasilkan bahwa diperoleh sinyal yang sangat dominan adalah sinyal curah hujan mendekati 6 bulanan. Sinyal tersebut memiliki kontribusi yang sangat tinggi, sehingga 
menyebabkan variasi diurnal pada sinyal harian tidak berpengaruh. Pada mode 2 terdapat variasi diurnal yang menyebabkan hujan di seluruh daratan di Indonesia. Mode 3 menghasilkan variasi diurnal yang berkebalikan dengan mode 2, yaitu menyebabkan hujan di seluruh Perairan di Indonesia. Akan tetapi kedua variasi diurnal yang muncul pada mode 2 dan mode 3 relatif kecil kontribusinya terhadap keseluruhan sinyal.

\section{TERIMA KASIH}

Penelitian ini dibiayai oleh Direktorat Riset dan Pengabdian Masyarakat, Direktorat Jenderal Penguatan Riset dan Pengembangan, Kementerian Riset, Teknologi, dan Pendidikan Tinggi, Sesuai dengan Kontrak Penelitian Tim Pasca Sarjana Nasional Tahun Anggaran 2017 Nomor: 011/SP2H/LT/DRPM/IV/2017, tanggal 20 April 2017

\section{DAFTAR PUSTAKA}

[1]. Anton H, Rorres C. Elementary Linear Algebra. Ed ke-10. New Jersey: J Wiley. 2010

[2]. Cheney W, Kincaid D. Numerical Mathematics and Computing, Ed ke-6. USA: Thomson. 2008.

[3]. Hamada J, Matsumoto J, Yamanaka MD. Spatial and Temporal Variations of the Rainy Season over Indonesia and their Link to ENSO, Journal of the Meteorological Society of Japan, Vol. 80 (2002), No. 2: 285-310.

[4]. Hannachi A. A primer for EOF analysis of climate data: Department of Meteorology, University of Reading, Reading RG6 6BB, UK. 2004.

[5]. Leon SJ. Linear Algebra with Applications. Ed ke-8. New Jersey: Prentice Hall. 2010.

[6]. Meyer CD. Matrix Analysis \& Applied Linear Algebra: Siam. 2000.

[7]. Navarra A, Simoncini V. A Guide to Empirical Orthogonal Function for Climate Data Analysis: Springer. 2010.

[8]. Nicholson WK. Elementary Linear Algebra. Singapore: McGraw-Hill. 2001.

[9]. Wiley E, Hansen. Fourier Transform: Principles and Applications. New Jersey: J Wiley. 2014. 